University of Nebraska - Lincoln

DigitalCommons@University of Nebraska - Lincoln

USDA National Wildlife Research Center - Staff Publications
U.S. Department of Agriculture: Animal and Plant Health Inspection Service

2012

\title{
An assessment of seedling damage by wild house mice (Mus musculus) and wild deer mice (Peromyscus spp.)
}

Gary W. Witmer

USDA-APHIS-Wildlife Services, gary.w.witmer@usda.gov

Nathan P. Snow

USDA/APHIS/WS National Wildlife Research Center, nathan.p.snow@aphis.usda.gov

Rachael S. Moulton

U.S. Department of Agriculture

Jenna L. Swartz

U.S. Department of Agriculture

Follow this and additional works at: https://digitalcommons.unl.edu/icwdm_usdanwrc

Witmer, Gary W.; Snow, Nathan P.; Moulton, Rachael S.; and Swartz, Jenna L., "An assessment of seedling damage by wild house mice (Mus musculus) and wild deer mice (Peromyscus spp.)" (2012). USDA National Wildlife Research Center - Staff Publications. 1213.

https://digitalcommons.unl.edu/icwdm_usdanwrc/1213

This Article is brought to you for free and open access by the U.S. Department of Agriculture: Animal and Plant Health Inspection Service at DigitalCommons@University of Nebraska - Lincoln. It has been accepted for inclusion in USDA National Wildlife Research Center - Staff Publications by an authorized administrator of DigitalCommons@University of Nebraska - Lincoln. 


\title{
An assessment of seedling damage by wild house mice (Mus musculus) and wild deer mice (Peromyscus spp.)
}

\author{
Gary W. Witmer, Nathan P. Snow, Rachael S. Moulton, and Jenna L. Swartz
}

\begin{abstract}
Although it is known that voles will damage seedlings, we do not know the extent to which deer mice (Peromyscus spp.) and house mice (Mus musculus Linnaeus, 1758) damage seedlings. Knowing this information can assist resource managers in better targeting problem species and implementing appropriate management actions. We planted and monitored ponderosa pine (Pinus ponderosa Douglas ex Lawson \& C. Lawson) and narrow-leaf cottonwood (Populus angustifolia E. James) seedlings in metal stock tanks occupied by deer mice or house mice to assess the potential for damage by these rodents. Both species damaged leaves and stems of cottonwood seedlings, but house mice did more damage. House mouse damage resulted in mortality of over half of the cottonwood seedlings, whereas deer mice caused a much lower level of seedling mortality. Only slight damage was done by either species to pine seedlings. Neither species damaged the roots of seedlings, despite the extensive burrowing by house mice. Although voles are often considered to be the primary rodent species causing seedling damage, we have shown that deer mice and especially house mice could also cause substantial damage to deciduous seedlings. However, our work suggests that rodent control to prevent damage to conifer seedlings might not be warranted in general unless there are extenuating circumstances and the species causing the damage are identified to assist with targeting control methods more precisely.
\end{abstract}

Résumé : Bien qu'on sache que les campagnols peuvent endommager les semis, on ne sait pas dans quelle mesure la souris sylvestre (Peromyscus spp.) et la souris domestique (Mus musculus Linnaeus, 1758) causent également des dommages aux semis. La réponse à cette question pourrait aider les gestionnaires à mieux cibler les espèces problématiques et à mettre en œuvre des actions d'aménagement appropriées. Nous avons mis en terre et suivi des semis de pin ponderosa (Pinus ponderosa Douglas ex Lawson \& C. Lawson) et de peuplier à feuilles étroites (Populus angustifolia E. James) dans des bacs de rangement en métal occupés par des souris sylvestres ou des souris domestiques pour évaluer les dommages que peuvent causer ces rongeurs. Les deux espèces ont causé des dommages aux feuilles et à la tige des peupliers à feuilles étroites. Les dommages causés par la souris domestique étaient nettement plus marqués, provoquant la mort de plus de la moitié des semis de peuplier à feuilles étroites tandis que la souris sylvestre causait beaucoup moins de mortalité. Les deux espèces de souris ont seulement causé des dommages mineurs aux semis de pin. Aucun dommage aux racines n'a été observé, même si la souris domestique creusait beaucoup de terriers. Bien que les campagnols soient souvent perçus comme l'espèce de rongeur qui cause le plus de dommages aux semis, notre étude montre que la souris sylvestre et surtout la souris domestique peuvent aussi causer des dommages considérables aux semis des essences feuillus. Toutefois, nos résultats indiquent que la répression des rongeurs pour prévenir les dommages aux semis des conifères n'est en général pas justifiée, sauf dans des cas spéciaux et lorsque les espèces qui causent les dommages sont identifiées de manière à mieux cibler les méthodes de répression.

[Traduit par la Rédaction]

\section{Introduction}

Rodents cause significant damage to a variety of resources required by a growing human population (Witmer and Singleton 2010). Damage can be especially severe when rodent population densities are high (Witmer and Proulx 2010).
House mice (Mus musculus Linnaeus, 1758) are one of the species implicated in various types of damage in urbansuburban and agricultural settings (Timm 1994; Witmer and Jojola 2006). In the urban-suburban setting, deer mice (Peromyscus spp.) can cause similar types of damage (Timm and Howard 1994: Salmon 2009). When house

Received 4 February 2012. Accepted 16 April 2012. Published at www.nrcresearchpress.com/cjfr on 23 May 2012.

G.W. Witmer, N.P. Snow, R.S. Moulton, and J.L. Swartz. U.S. Department of Agriculture Animal and Plant Health Inspection Service, Wildlife Services, National Wildlife Research Center, 4101 Laporte Avenue, Fort Collins, CO 80521-2154, USA.

Corresponding author: Gary Witmer (e-mail: gary.w.witmer@aphis.usda.gov). 
mice are introduced to islands, they can cause environmental harm by feeding on seeds, seedlings, various invertebrates, and even vertebrates in some cases (Angel et al. 2009). In many cases, the potential for impacts from house mice can increase once invasive rats are removed. This is because mice populations often irrupt after rat eradication, presumably because the mice are no longer under intense predation and competition pressures (Caut et al. 2007; Witmer et al. 2007a). Consequently, damage by house mice can be expected to increase after an invasive rat eradication.

A variety of methods are commonly used to reduce damage by rodents; these methods are generally framed within an integrated pest management (IPM) strategy (Witmer 2007). Because rodents provide important ecosystem roles and because not all species present may be causing the damage observed, it is important to determine the role of each species. For example, regeneration of trees and shrubs on restored landfills in Brooklyn, New York, is being hindered by rodents. Several species (e.g., voles (Microtus spp.), deer mice, and house mice) occur there, and it is not known how much damage is being caused by each species. Deer mice, house mice, and voles do co-exist on agricultural lands, airport grasslands, and restored landfills being converted to parklands at various locations in North America (G.W. Witmer, unpublished data). The assumption has been that voles are the main species causing seedling damage (e.g., Askham 1992; O’Brien 1994), but damage to seedlings by deer mice and house mice has not been assessed and quantified.

The potential for damage to vegetation by house mice has been studied on some islands and in countries where house mice have become established in natural settings (e.g., Wilson et al. 2006; Angel et al. 2009). Both house mice (Ruscoe et al. 2005) and deer mice (Nolte and Barnett 2000; Sullivan and Sullivan 1982) are known to feed heavily on seeds, enough so as to hinder reforestation efforts and crop production. However, there is relatively little documentation of seedling damage by deer mice or house mice in North America. This study sought to provide a preliminary answer to the damage question of whether or not non-native house mice and native deer mice control on islands, in other natural settings, and in commercial orchards and forestlands is warranted. Our objective was to determine the level of damage to two species of seedlings by house mice and deer mice in a controlled enclosure setting. We hypothesized that house mice and deer mice would cause damage to seedlings even when other food resources were available.

\section{Methods}

Wild house mice and wild deer mice were live-trapped in Fort Collins, Colorado, using Sherman aluminum traps (H.B. Sherman Traps, Tallahassee, Florida). Mice were transported to an outdoor rodent building (ORB) of the USDA National Wildlife Research Center, Fort Collins, Colorado, where each one was weighed, sexed, and dusted with an insecticide powder to kill ectoparasites. Each mouse was placed in an individual plastic cage with a wire mesh lid, which was placed on a wire metal shelving unit for a 2 -week quarantine period. Animals were fed rodent chow and a slice of apple daily.
Each cage was equipped with a water bottle, bedding, and a cardboard den tube.

The seedling trials were conducted in eight metal livestock water tanks (each approximately $2 \mathrm{~m}$ in diameter) in an ORB. Each tank was filled with about $20 \mathrm{~cm}$ of topsoil. Containerized seedlings were obtained from the Colorado State Forest Service Nursery, Fort Collins, Colorado. We used a species of deciduous tree (narrow-leafed cottonwood, Populus angustifolia E. James) and a species of coniferous tree (ponderosa pine, Pinus ponderosa Douglas ex Lawson \& C. Lawson). The cottonwood seedling heights (mean $=33.1 \mathrm{~cm}$, $\mathrm{SD}=3.7)$ were significantly greater $(t=13.44, P=0.0000)$ than the pine seedling heights (mean $=13.4, \mathrm{SD}=1.8$ ), which is typical because of the fast-growing nature of cottonwood seedlings. The soil was watered before the seedlings were planted. In each tank, we systematically planted 10 seedlings (five cottonwood and five pine) with approximately equal spacing between each seedling using a hand trowel. Six seedlings comprised a circle around the perimeter of the tank and four were in a square in the interior of the tank around a central water container. We alternated cottonwood and pine seedlings so that for the majority, two of the same species were not next to each other. Seedlings were each assigned an individual number, 1-10 with a code letter of "c" (conifer) or "d" (deciduous) to denote the species type. Seedlings were watered daily with a hand-held watering can.

In addition to the seedlings, each tank contained two den boxes near opposite sides of the tank, and some small rocks were scattered about the surface. Some grass hay was placed on the surface. A small chicken or pet watering device (e.g., inverted water reservoir surrounded by a small circular trough that stays filled with water) was placed on the soil surface in the center of the tank. A nearby control tank (i.e., no mice) contained six seedlings (three cottonwood and three pine). The purpose of the control tank was only to provide the simple observation that all seedlings protected from depredation ordinarily survive over the course of the experiment. The control tank was not used in statistical comparisons, which were limited to comparisons of seedling damage among species and treated tanks.

For the first trial, four house mice (three females and one male) were randomly assigned and placed in each tank. Mice inside each tank were fed four to six pieces of rodent chow and four to six small slices of apple. Seedling condition was monitored twice daily for 3 weeks, with each being recorded as undamaged, damaged, dead, or missing. Damage to the leaves or needles was considered as missing, partially missing, or broken leaves or needles. Damage to the stem was considered as severed stem, partially severed stem, girdling of stem, or digging under the stem. We also maintained counts of the number of leaves remaining on each cottonwood over time.

At the end of the 3-week seedling monitoring session, all food was removed from the tanks, and the mice were livetrapped and returned to individual cages. Seedlings were carefully removed with a hand trowel and laid on a sheet of cardboard with the seedling number written on the cardboard. Each was thoroughly examined again and labeled as undamaged, slightly damaged (a few leaves or needles damaged), or severely damaged (numerous leaves or needles and (or) stem damaged), and location of damage (leaves or needles, stem, 
Table 1. Damage by wild house mice (Mus musculus) and wild deer mice (Peromyscus spp.) to deciduous and coniferous seedlings planted in metal tanks containing top soil.

\begin{tabular}{|c|c|c|c|c|c|c|c|c|}
\hline \multirow[b]{2}{*}{ Tank } & \multicolumn{4}{|l|}{ House mice } & \multicolumn{4}{|l|}{ Deer mice } \\
\hline & Undamaged & $\begin{array}{l}\text { Slightly } \\
\text { damaged }\end{array}$ & $\begin{array}{l}\text { Severely } \\
\text { damaged }\end{array}$ & Dead & Undamaged & $\begin{array}{l}\text { Slightly } \\
\text { damaged }\end{array}$ & $\begin{array}{l}\text { Severely } \\
\text { damaged }\end{array}$ & Dead \\
\hline \multicolumn{9}{|c|}{ (A) Deciduous seedlings } \\
\hline 1 & 1 & 0 & 4 & 0 & 1 & 3 & 1 & 0 \\
\hline 2 & 0 & 0 & 5 & 5 & 0 & 1 & 4 & 1 \\
\hline 3 & 0 & 0 & 5 & 5 & 0 & 0 & 5 & 5 \\
\hline 4 & 0 & 2 & 3 & 3 & 0 & 3 & 2 & 0 \\
\hline 5 & 0 & 0 & 5 & 5 & 0 & 1 & 4 & 0 \\
\hline 6 & 0 & 1 & 5 & 2 & 2 & 0 & 3 & 0 \\
\hline 7 & 1 & 0 & 4 & 4 & 1 & 3 & 1 & 0 \\
\hline 8 & 0 & 1 & 2 & 2 & 0 & 0 & 5 & 4 \\
\hline Total & 2 & 4 & 33 & 26 & 4 & 11 & 25 & 10 \\
\hline Mean & 0.25 & 0.50 & 4.13 & 3.25 & 0.50 & 1.34 & 3.13 & 1.25 \\
\hline SD & 0.46 & 0.76 & 1.13 & 1.83 & 0.76 & 1.41 & 1.64 & 2.05 \\
\hline \multicolumn{9}{|c|}{ (B) Coniferous seedlings } \\
\hline 1 & 1 & 3 & 1 & 0 & 4 & 1 & 0 & 0 \\
\hline 2 & 0 & 3 & 2 & 0 & 4 & 1 & 0 & 0 \\
\hline 3 & 0 & 4 & 1 & 0 & 4 & 1 & 0 & 0 \\
\hline 4 & 5 & 0 & 0 & 0 & 5 & 0 & 0 & 0 \\
\hline 5 & 0 & 5 & 0 & 0 & 4 & 1 & 0 & 0 \\
\hline 6 & 0 & 5 & 0 & 0 & 5 & 0 & 0 & 0 \\
\hline 7 & 1 & 4 & 0 & 0 & 5 & 0 & 0 & 0 \\
\hline 8 & 3 & 1 & 1 & 0 & 4 & 1 & 0 & 0 \\
\hline Total & 10 & 25 & 5 & 0 & 35 & 5 & 0 & 0 \\
\hline Mean & 1.25 & 3.13 & 0.63 & 0 & 4.33 & 0.75 & 0 & 0 \\
\hline $\mathrm{SD}$ & 1.83 & 1.81 & 0.74 & 0 & 0.05 & 0.46 & 0 & 0 \\
\hline
\end{tabular}

Note: Each tank had five deciduous seedlings and five coniferous seedlings. Dead seedlings are also listed as severely damaged seedlings (i.e., this is not an independent category). SD, standard deviation.

roots), number of remaining leaves, and mortality were noted.

The tanks were then prepared for the next trial with deer mice. Den boxes and the water containers were washed and the soil was mixed and raked to a smooth surface. Seedlings were planted and rocks and hay were scattered about the surface. Den boxes and the water containers were placed in the same positions as in the previous trial. The trial was then repeated as per the previous trial with house mice. Safety precautions were taken with the deer mice trial, however, because of the potential hazard of hantavirus: respirators, Tyvek suits, latex gloves, and rubber boots (sanitized in a foot bath upon entering and exiting the room) were worn by study personnel. At the end of the study, all mice were euthanized with $\mathrm{CO}_{2}$ after anesthesia with isoflurane.

We used the program Statistix (version 9, Analytical Software, Tallahassee, Florida) to analyze the data sets. Comparisons for independence and significant differences were made between numbers of seedlings (damaged versus undamaged, alive versus dead, deciduous versus coniferous, house mice versus deer mice) using Pearson's chi-square $\left(\chi^{2}\right)$ test and $t$ tests. For purposes of statistical analyses, we combined undamaged seedlings and slightly damaged seedlings into one category for comparisons with severely damaged seedlings. A $P$ value of $\leq 0.05$ was considered to indicate a significant difference.

\section{Results}

All control seedlings were alive, undamaged, and appeared healthy at the end of the study. Eighty seedlings (40 deciduous and 40 coniferous) were exposed to house mice and to deer mice, respectively. Both rodent species damaged seedlings (Table 1; Fig. 1), but house mice damaged significantly more $\left(\chi^{2}=4.38, P=0.0364\right)$ seedlings (39 of 80$)$ than did deer mice (26 of 80 ). House mice damaged both deciduous (34 of 40) and coniferous seedlings (5 of 40), but damaged significantly more $\left(\chi^{2}=42.08, P \leq 0.0001\right)$ deciduous seedlings than coniferous seedlings. Deer mice damaged deciduous seedlings (25 of 40), but not coniferous ( 0 of 40). House mice damaged significantly more $\left(\chi^{2}=5.23, P=0.0222\right)$ deciduous seedlings than did deer mice. House mice caused the mortality of significantly more $\left(\chi^{2}=12.93, P=0.0003\right)$ deciduous seedlings (26 of 40) than did deer mice (10 of 40). In all cases of deciduous seedling mortality, all or almost all leaves had been removed. Neither species of rodent caused mortality to coniferous seedlings.

In the house mouse tanks, significantly more $(t=9.90$, $P \leq 0.0001)$ deciduous seedlings were damaged (mean = $4.25, \mathrm{SD}=0.71$ ) than undamaged (mean $=0.75, \mathrm{SD}=$ 0.71). In those same tanks, the reverse was true with coniferous seedlings, where significantly fewer $(t=-10.08, P=$ 0.0000 ) were damaged (mean $=0.63, \mathrm{SD}=0.74$ ) than undamaged $($ mean $=4.38, \mathrm{SD}=0.74)$. Although deer mice 
Fig. 1. Percentage of undamaged (includes slightly damaged seedlings) versus severely damaged (includes dead seedlings) seedlings by seedling type (Dec, deciduous; Con, coniferous) by wild deer mice (Deer M; Peromyscus spp.) and wild house mice (House M; Mus musculus).

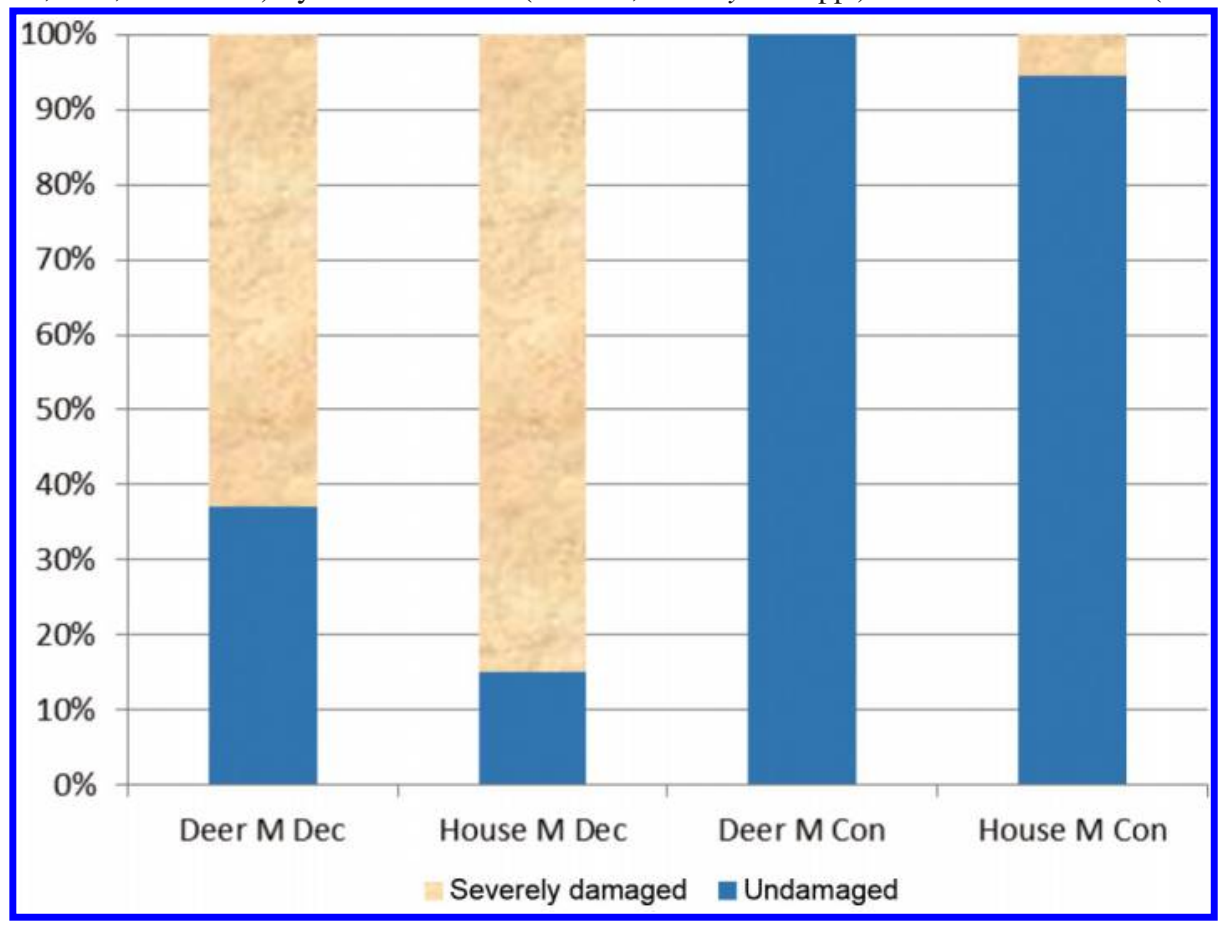

damaged deciduous seedlings, there was not a significant difference $(t=1.52, P=0.1502)$ between the number damaged (mean $=3.13, \mathrm{SD}=1.64)$ compared with undamaged (mean $=1.88, \mathrm{SD}=1.64)$ in the deer mouse tanks.

Neither deer mice nor house mice damaged the root system of the seedlings. This was the case despite the extensive burrowing by house mice. House mice created significantly more $(t=9.51, P \leq 0.0001)$ burrow openings (mean $=9.13$, $\mathrm{SD}=2.42)$ than did deer mice $($ mean $=0.63, \mathrm{SD}=0.74)$. Deer mice did very little burrowing, preferring to use the den boxes or shallow depressions in the soil for nests and shelter.

\section{Discussion}

Voles are known for damaging tree seedlings and even mature trees (Askham 1992; O'Brien 1994). Until now, the extent that deer mice and house mice damage to seedlings was unclear. We determined that both species damage deciduous seedlings but appear to pose little threat to coniferous seedlings. We could not determine whether the extensive damage caused by house mice to deciduous seedlings was due to feeding, gnawing behavior, or gathering material for nests, but it is possible that several of these activities were involved. We know that voles cause extensive root damage (Askham 1992; O’Brien 1994), but we did not document any root damage by house mice or deer mice, despite extensive burrowing by house mice.

Our results suggest that damage to coniferous seedlings by house mice and deer mice is not an issue that resource managers need to address. We note, however, that Graham and Kingery (1990) reported low levels of Ponderosa pine seedling mortality $(1 \%-7 \%)$ and damage $(0.3 \%-3.9 \%)$ by rodents in Idaho. They did not specifically identify the species of rodent and used the general category of "rodent", which pre- sumably included deer mice. They had a separate category for pocket gophers (Thomomys spp.), which were reported to cause substantial mortality $(0.7 \%-60.6 \%)$ and damage $(0.3 \%-$ $9.5 \%)$ to the pine seedlings. Côté et al. (2003) reported that in Canada, mice (deer mice and voles combined) occasionally caused low levels of small seedling damage to black spruce (Picea mariana) in some years, especially on recently burned regeneration sites.

We speculate that deciduous seedling damage by house mice and deer mice ordinarily might not pose a significant threat in unconfined areas with abundant food resources (herbaceous plants, seeds, invertebrates), in part because such damage has not been reported in the scientific literature. However, during times of food scarcity (late fall through early spring) or drought (less herbaceous plant growth and less seed production), damage to deciduous seedlings might occur. This is probably why less damage to apple trees was found by Sullivan and Sullivan (1988) when supplemental food was applied to the area. During times of increased rodent densities, more damage may also occur (Witmer and Proulx 2010; Witmer and Singleton 2010). Hence, under a variety of conditions and settings, management actions to reduce that damage on regeneration sites or in plant nurseries may be warranted. Such management actions might include protective barriers (e.g., Marsh et al. 1990), repellents (e.g., Nolte and Barnett 2000), ground vegetation management (e.g., Sullivan and Vandenbergh 2000; Witmer et al. 2007b), diversionary foods (Sullivan et al. 2001), or reduction of rodent populations using rodenticides or traps (Witmer 2007; Witmer and Singleton 2010). However, our work suggests that rodent control to prevent damage to conifer seedlings might not be warranted in general unless there are extenuating circumstances and the species causing the damage are identified to assist with targeting control methods more pre- 
cisely. For example, a rodenticide bait formulation could be selected that is more palatable to house mice than deer mice or the rodenticide bait can be used in a delivery system that will largely preclude access to baits by some nontargeted species of rodents. It is also important to make sure that the targeted rodent species is listed on the regulatory agency approved rodenticide label.

\section{Acknowledgments}

This study was funded by the U.S. Department of Agriculture Wildlife Services. The study was conducted under the NWRC IACUC approved study protocol QA-1754. We thank the various landowners for allowing us to trap mice on their properties for use in this study.

\section{References}

Angel, A., Wanless, R., and Cooper, J. 2009. Review of impacts of the introduced house mouse on islands in the Southern Ocean: are mice the equivalent to rats? Biol. Invasions, 11(7): 1743-1754. doi:10.1007/s10530-008-9401-4.

Askham, L. 1992. Voles. In Silvicultural approaches to animal damage management in Pacific Northwest forests. Edited by H.C. Black. USDA Forest Service, Portland, Oregon, General Technical Report PNW-GTR-287. pp. 187-205.

Caut, S., Casanovas, J., Virgos, E., Lozano, J., Witmer, G., and Courchamp, F. 2007. Rats dying for mice: modeling the competitor release effect. Austral Ecol. 32(8): 858-868. doi:10. 1111/j.1442-9993.2007.01770.x.

Côté, M., Ferron, J., and Gagnon, R. 2003. Impact of seed and seedling predation by small rodents on early regeneration establishment of black spruce. Can. J. For. Res. 33(12): 23622371. doi:10.1139/x03-167.

Graham, R., and Kingery, J. 1990. Seedling damage and mortality of conifer plantations on transitory ranges in northern and central Idaho. In Proceedings of the 14th Vertebrate Pest Conference, Sacramento, California, 6-8 March 1990. Edited by L. Davis and R. Marsh. University of California, Davis, California. pp. 209213.

Marsh, R., Koehler, A., and Salmon, T. 1990. Exclusionary methods and materials to protect plants from pest mammals: a review. In Proceedings of the 14th Vertebrate Pest Conference, Sacramento, California, 6-8 March 1990. Edited by L. Davis and R. Marsh. University of California, Davis, California. pp. 174-180.

Nolte, D., and Barnett, J. 2000. A repellent to reduce mouse damage to longleaf pine seed. Int. Biodeterior. Biodegradation, 45(3-4): 169-174. doi:10.1016/S0964-8305(00)00060-3.

O'Brien, J. 1994. Voles. In Prevention and control of wildlife damage. Edited by S. Hygnstrom, R. Timm, and G. Larsen. Cooperative Extension Division, University of Nebraska, Lincoln, Nebraska. pp. B-177-B-182.

Ruscoe, W., Elkinton, J., Choquenot, D., and Allen, R. 2005. Predation of beech seed by mice: effects of numerical and functional responses. J. Anim. Ecol. 74(6): 1005-1019. doi:10. 1111/j.1365-2656.2005.00998.x.

Salmon, T. 2009. Vertebrate pest control handbook. University of
California-Davis, Davis, California. Available at http://vpcrac.org/ about/handbook.php [accessed 17 February 2010].

Sullivan, T., and Sullivan, D. 1982. Use of alternative foods to reduce lodgepole pine seed predation by small mammals. J. Appl. Ecol. 19(1): 33-45. doi:10.2307/2402989.

Sullivan, T., and Sullivan, D. 1988. Influence of alternative foods on vole populations and damage in apple orchards. Wildl. Soc. Bull. 16: $170-175$.

Sullivan, W., and Vandenbergh, J. 2000. A comparison of grass covers and meadow vole populations in North Carolina. In Proceedings of the 9th Wildlife Damage Management Conference, State College, Pennsylvania, 5-8 October 2000. Edited by M. Brittingham, J. Kays, and R. McPeake. Pennsylvania State University, University Park, Pennsylvania. pp. 300-306.

Sullivan, T.P., Sullivan, D.S., and Hogue, E.J. 2001. Influence of diversionary foods on vole (Microtus montanus and Microtus longicaudus) populations and feeding damage to coniferous tree seedlings. Crop Prot. 20(2): 103-112. doi:10.1016/S0261-2194 (00)00062-4.

Timm, R. 1994. House mice. In Prevention and control of wildlife damage. Edited by S. Hygnstrom, R. Timm, and G. Larsen. University of Nebraska, Cooperative Extension Service, Lincoln, Nebraska. pp. B-31-B-46.

Timm, R., and Howard, W. 1994. Deer mice. In Prevention and control of wildlife damage. Edited by S. Hygnstrom, R. Timm, and G. Larsen. University of Nebraska, Cooperative Extension Service, Lincoln, Nebraska. pp. B-47-B-51.

Wilson, D., Ruscoe, W., Burrows, L., McElrea, L., and Choquenot, D. 2006. An experimental study of the impacts of understorey forest vegetation and herbivory by red deer and rodents on seedling establishment and species composition in Waitutu Forest, New Zealand. N.Z. J. Ecol. 30: 191-207.

Witmer, G. 2007. The ecology of vertebrate pests and integrated pest management. In Prospectives in ecological theory and integrated pest management. Edited by M. Kogan and P. Jepson. Cambridge University Press, Cambridge, UK. pp. 393-410.

Witmer, G., and Jojola, S. 2006. What's up with house mice? - a review. In Proceedings of the 22nd Vertebrate Pest Conference, Berkeley, California, 6-9 March 2006. Edited by R. Timm and J. O'Brien. University of California, Davis, California. pp. 124-130.

Witmer, G., and Proulx, G. 2010. Rodent outbreaks in North America. In Rodent outbreaks: ecology and impacts. Edited by G. Singleton, S. Belmain, P. Brown, and B. Hardy. International Rice Research Institute, Los Banos, Philippines. pp. 253-267.

Witmer, G., and Singleton, G. 2010. Sustained agriculture: the need to manage rodent damage. In Agricultural production. Edited by $\mathrm{F}$. Wager. Nova Science Publishers, Inc., New York. pp. 1-38.

Witmer, G.W., Boyd, F., and Hillis-Starr, Z. 2007a. The successful eradication of introduced rats (Rattus rattus) from Buck Island using diphacinone, followed by an irruption of house mice (Mus musculus). Wildl. Res. 34: 108-115. doi:10.1071/WR06006.

Witmer, G., Sayler, R., Higgins, D., and Capelli, J. 2007b. Ecology and management of rodents in no-till agriculture in Washington, USA. Integr. Zool. 2(3): 154-164. doi:10.1111/j.1749-4877.2007. 00058.x. PMID:21396031. 